\title{
FINOMMECHANIKAI ELEM ERŐ-ELMOZDULÁS DIAGRAMJÁNAK MEGHATÁROZÁSA SPECIÁLIS ROBOTMEGFOGÓVAL
}

\author{
Rónai László \\ doktorandusz, Miskolci Egyetem, Szerszámgépészeti és Mechatronikai Intézet, \\ Robert Bosch Mechatronikai Intézeti Tanszék \\ 3515 Miskolc, Miskolc-Egyetemváros, e-mail: ronai.laszlo@uni-miskolc.hu \\ Szabó Tamás \\ egyetemi docens, Miskolci Egyetem, Szerszámgépészeti és Mechatronikai Intézet, \\ Robert Bosch Mechatronikai Intézeti Tanszék \\ 3515 Miskolc, Miskolc-Egyetemváros, e-mail: szabo.tamas@uni-miskolc.hu
}

\begin{abstract}
Absztrakt
A cikk egy korábban kifejlesztett intelligens robotmegfogó ellenörzési folyamatokra való alkalmazhatóságát tárgyalja egy konkrét példán keresztül. A szerkezet tartalmaz egy erömérö cellát és egy mikrovezérlöt az erömérés elvégzéséhez. A megfogó egység ezen felül alkalmas szerelési folyamatok intelligens végrehajtására is. Egy müanyag akkumulátor tartó fedél részösszeállitásán keresztül bemutatásra kerül a fedélben található spirál rugó erö-elmozdulás karakterisztikájának felvétele. A kapott eredmények lehetöséget adhatnak adott szerkezetek minöségbiztositási kiértékelésére.
\end{abstract}

Kulcsszavak: intelligens megfogó, mechatronika, erö-elmozdulás diagram, mikrokontroller, robot

\begin{abstract}
This paper deals with the applicability of a previously developed intelligent end effector in checking processes through a specific example. The unit contains a load cell and a microcontroller to measure and process the force values. The end effector is also applicable for intelligent robotic assembly operations. Through a subassembly of a cover of a plastic battery holder, the measurement of the loaddeflection diagram of a helical spring, which is in the cover, is presented. The results obtained may provide an opportunity to perform a quality control process of different structures.
\end{abstract}

Keywords: intelligent end effector, mechatronics, load-deflection diagram, microcontroller, robot

\section{Bevezetés}

A folyamatok automatizálása a régmúlt időkre tekint vissza [1]. Napjainkban a robottal elvégzett ipari feladatok tárháza a felmerülő igényeknek köszönhetően folyamatosan bővül [2,3]. Erre mi sem mutathatna jobb példát, mint a különböző szerelési folyamatokat alkalmazó gyáraknál tapasztalható nagymérvủ robotizálás pl. az autóiparban [4].

Minden gyártási folyamatnak részét képezi az ellenőrzés, hiszen a gyártandó termék minősége egy igen fontos vevői elvárás. Minőségellenőrzési célokra a gyárakban gyakran emberi erőforrást alkalmaznak, azonban a különböző kamerarendszerek megjelenésével [5] az ellenőrzési folyamatok egyre nagyobb része automatizálhatóvá vált. Azonban felmerülhetnek olyan ellenőrzési feladatok is, ahol az adott alkatrész müködtetéshez szükséges erőt kell meghatározni pl. az idő- vagy az út függvényében [6]. 
Jelen cikkben egy kéziszerszámhoz csatlakozó akkumulátor pakk fedelének részösszeállításában található rugó-csap szerkezet erö-elmozdulás diagramjának felvétele történik meg egy, már korábban kifejlesztett intelligens megfogóval [7,8]. Az intelligens megfogó robottal történő stabilitásvesztéssel járó szerelési folyamatok elvégzésre is alkalmazható [9]. A megfogó egy erőmérő cellát tartalmaz, amelynek mért analóg értékeit egy 24 bites A/D átalakító fogja digitalizálni, majd egy ATmega 328 típusú mikrovezérlőnek továbbküldeni.

A cikk 2. fejezete ismerteti a megfogó egységgel elvégzett erő-elmozdulás diagram felvételének módszerét. A megfogó egy 6 szabadsági fokkal rendelkező Fanuc gyártmányú ipari robotra lett felszerelve. A 3. fejezet tartalmazza az elvégzett mérés összefoglalását.

\section{Erő-elmozdulás diagram felvételének folyamata}

A kifejlesztett intelligens robotmegfogó $[7,8]$ a szerelési müveleteken felül, minőségellenőrzési jellegü feladatokra is alkalmazható. A gyárakban több olyan ellenőrzési folyamat fordulhat elö, amikor az összeszerelt munkadarab vagy egy részösszeállítás megfelelőségét kell vizsgálni, és összevetni egy referencia értékkel pl. rugóerő mérése, kiegyensúlyozó klipszek felhelyezéséhez szükséges erőérték mérése, stb.

A cikk egy műanyag fedélben található nyelv erő-elmozdulás diagramjának felvételével foglalkozik. A részösszeállítás egy spirál rugót, egy müanyag csapot és a fedelet foglalja magában. Az egységet elemeivel az 1. ábra szemlélteti.

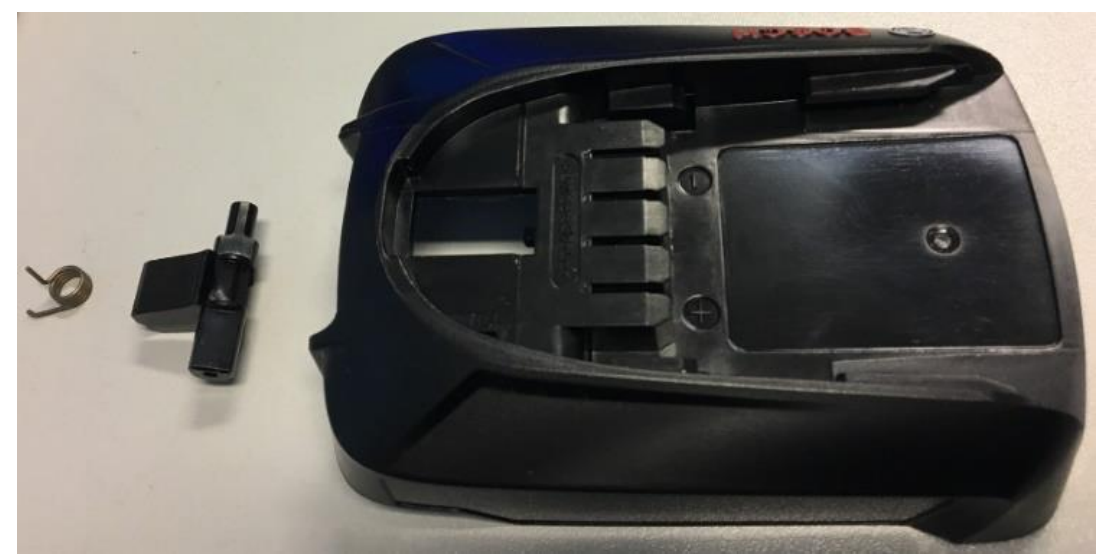

1. ábra. Akkumulátor tartó egység fedele és elemei

A szerelési részfolyamat első lépésében a rugó rákerül a csapra, majd a csapot bepattanással kell a müanyag házba beszerelni. A rugó a nyelvet kiemeli a fedél síkjából. A nyelv fogja biztosítani, hogy egy kéziszerszámhoz rögzíteni lehessen az akkumulátor pakkot.

A már korábban kifejlesztett intelligens megfogó blokkvázlatát mutatja a 2. ábra, amely egy Fanuc gyártmányú ipari robottal van összekapcsolva digitális ki- és bemeneteken keresztül. A szerkezet tartalmaz egy pneumatikus megfogót, amit az intelligens robotmegfogó egységre szerelünk. A benne található mikrokontroller dolgozza fel az erőmérő által szolgáltatott erőértékeket egy 24 bites szigmadelta A/D átalakító közremüködésével, amelyeket UART kommunikációs protokoll segítségével fog továbbítani pl. egy laptopra, amelyen egy sajátfejlesztésü mérésadatgyüjtő programmal rögzíthetők lesznek az erő-elmozdulás diagramok. 
Mivel a robot digitális be- és kimenetei $24 \mathrm{~V}$ jelszinten-, a mikrokontroller be-, illetve kimenetei pedig $5 \mathrm{~V}$ jelszinten üzemelnek, így a jelszintillesztés érdekében az egység optocsatolókat tartalmaz. A robot-mikrovezérlő közötti kommunikáció fontossága leginkább a szerelési folyamatok intelligens elvégzésénél mutatkozik [7]. Jelen feladatnál a robot egy digitális kimenete fogja a mikrovezérlő változóinak kezdeti értékeit beállítani és egy bemenete felel a folyamat közbeni túlterhelés elkerülésére.

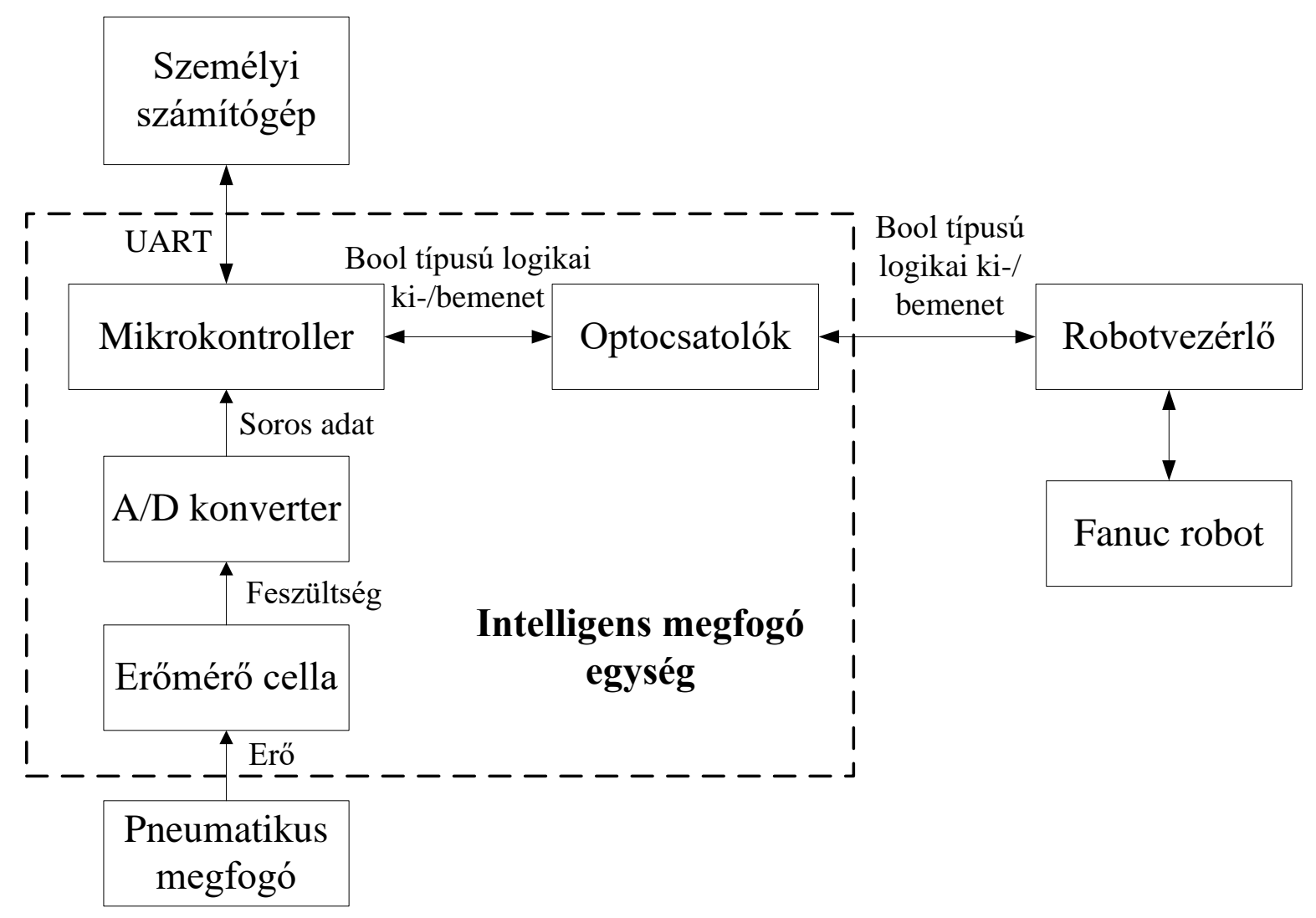

\section{2. ábra. A mérörendszer blokkvázlata}

Annak érdekében, hogy csak működtetés irányú erőkomponenst lehessen mérni, az egység tartalmaz egy két lemezből álló rugalmas párhuzamos mechanizmust [10].

A műanyag nyelv erö-elmozdulás diagramjának felvételekor, annak lenyomási útja függvényében a megfogó a rugóerőt meghatározza és a mért maximum értéket össze tudja vetni pl. a gyár által elöírt referencia értékekkel. A mérési összeállítást a 3. ábrán lehet megfigyelni. A mérési eredmények akár a felhőben is tárolhatók az Ipar 4.0 koncepció szerint.

A mérés során a pneumatikus megfogó egy csappal müködteti a nyelvet. A mikrovezérlö- és a robotprogram is tartalmaz egy-egy biztonsági feltételt, amelynek értelmében, ha a folyamat során mérendő erő nagyobb, mint $50 \mathrm{~N}$, akkor a robot felhagy az ellenőrzéssel és vissza fog állni az alaphelyzetébe. A laptopon futó mérésadatgyüjtő program megjeleníti a mért erőértékeket és a mérés végeztével .csv fájlformátumban lementhetők. 


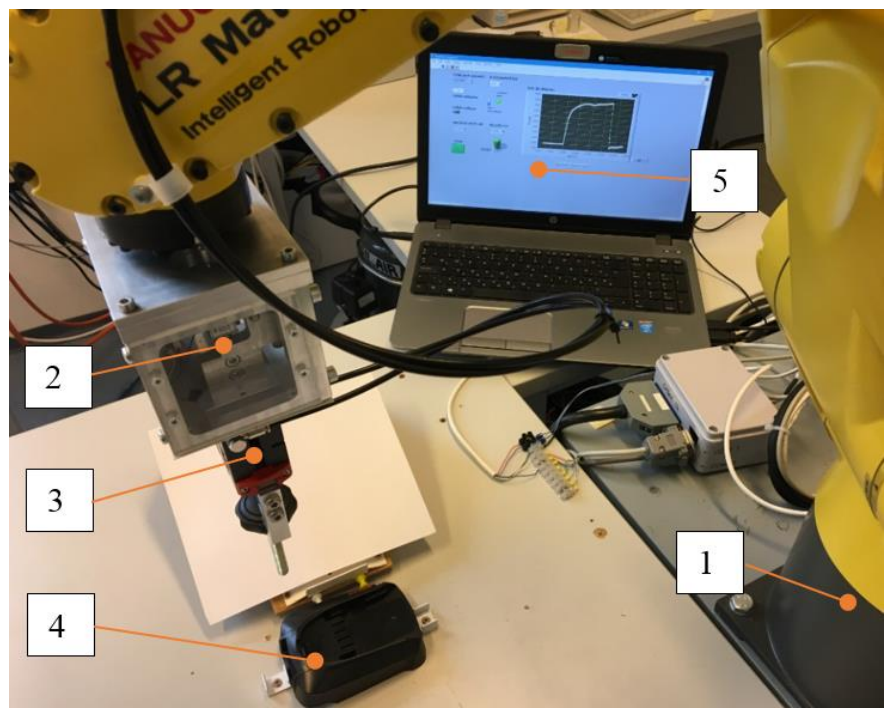

3. ábra. A tesztrendszer elemei: 1-Fanuc ipari robot; 2-intelligens robotmegfogó; 3-pneumatikus megfogó; 4-müanyag akkumulátor fedél; 5-laptop

A roboton futó programot az 1. táblázat tartalmazza, az 1. sorban történik a robot felhasználói- és szerszám koordinátarendszerének definiálása.

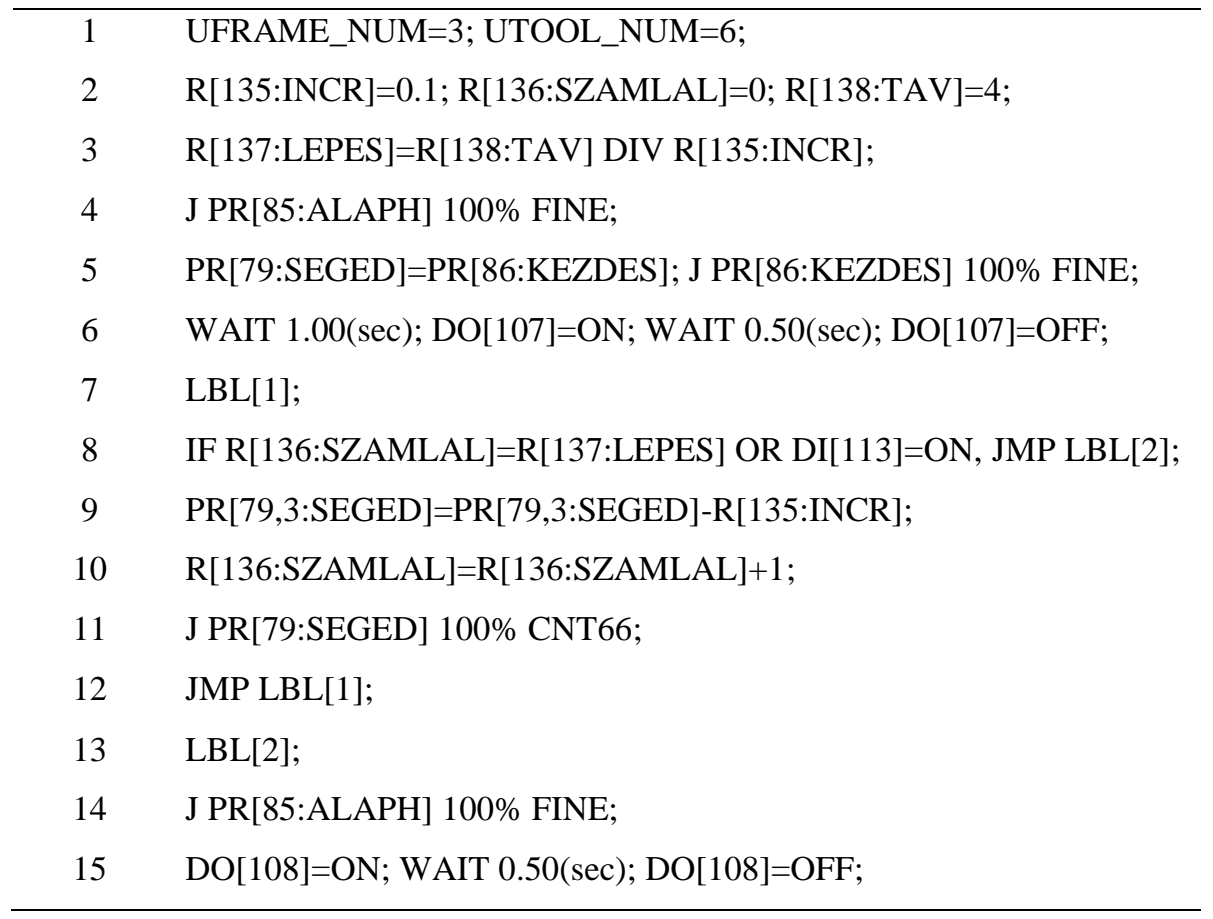

1. táblázat. A robotprogram 
A 2. és a 3. sorok tartalmazzák a változók deklarálását, amelyeket regiszterek tárolnak. Az elmozdulás növekmény (INCR) $0,1 \mathrm{~mm}$ lesz, a maximális elmozdulás (TAV) pedig $4 \mathrm{~mm}$. A 4 . sorban a robot egy elöre definiált alaphelyzetbe fog mozogni. Az 5. programsorban a robot a müanyag nyelv müködtetéséhez szükséges kiindulási helyzetbe fog menni, de elötte egy segéd pozícióregiszter megkapja ennek a helyzetnek a koordinátáit. A robot a 107. sorszámú digitális kimenetén (DO[107]) jelet küld a megfogó egységnek, hogy a mikrovezérlő a megfelelő változóinak kezdeti értékét be tudja állítani.

A 7. sorban található a Címke $1(L B L[1])$ definiálása. A 8. sorban lévő feltétel alapján, ha a robot végrehajtja a meghatározott számú (LEPES) elmozdulás növekményt vagy a mikrovezérlő $50 \mathrm{~N}$-nál nagyobb erőt regisztrál mérés közben $(D I[113]=O N)$, akkor a robotprogram átugrik a 13. sorban található Címke $2(L B L[2])$ részre, amely után a robot alaphelyzetébe fog mozogni. Egyébként, amíg a feltétel nem teljesül a robot $0,1 \mathrm{~mm}$ elmozdulás növekménnyel vertikális irányban fog lefelé mozogni, mivel a 12. sorban visszaugrik a 7. sorban található Címke 1 ( $L B L[1])$ részre.

A mérésadatgyüjtő program által eltárolt adatokat Scilab szoftverbe importálva, majd megjelenítve mutatja a 4. ábra.

Az erö-elmozdulás diagram alapján látható, hogy a nyelv müködtetéséhez maximálisan $7-8 \mathrm{~N}$-ra van szükség. Kezdetben a karakterisztika kb. 0,2 mm elmozdulásig lineáris-, majd $5 \mathrm{~N}$ terhelés után elöször lágyuló jelleget-, majd kvázi-stagnáló értéket mutat a további 3,5 $\mathrm{mm}$ úton. A lágyuló jelleg azzal magyarázható, hogy az 1 . ábrán szemléltetett spirál rugó a lecsévélés forgásirányában terhelt a nyelv benyomása folyamán. A rugó axiális irányú egyenes szakasza a csap furatában rögzítve van, az érintő irányú kampós-konzolos vég pedig a fedélbe támaszkodik. A nyelv terhelésekor ez a konzolos vég lecsévélődik, ezáltal a konzol hossza növekszik, amely a rugó karakterisztika lágyulását okozza.

Ezen adatokat az Ipar 4.0 koncepció alapján célszerü felhőben is tárolni, majd nyomon követni a beszállító által biztosított termékek minőségi alakulását is.

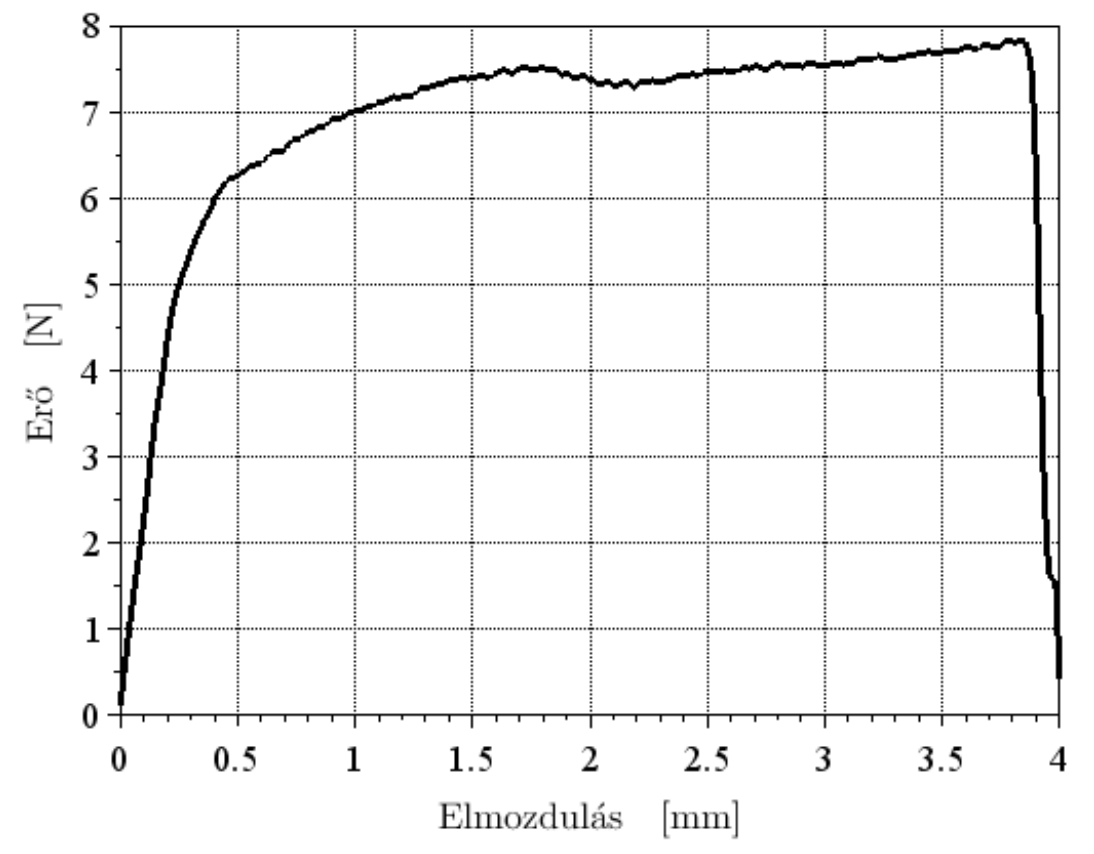

4. ábra. A mérés során kapott erö-elmozdulás diagram 


\section{3. Összefoglalás}

A cikk egy már korábban kifejlesztett, ipari robotokra szerelhető intelligens robotmegfogóval elvégezhető konkrét minőségellenőrzési feladattal foglalkozott. A megfogó nemcsak ellenőrzési-, hanem szerelési folyamatok intelligens kivitelezésére is alkalmas. Az egység robotra, vagy akár egy célgépre is rögzíthető az ellenőrzési folyamatok során.

A cikkben egy ipari robottal megvalósított mérés történt meg. Egy müanyag fedélben található nyelv müködtetéséhez szükséges erő meghatározása valósult meg a lenyomási út függvényében. A kapott nemlineáris függvény alapján kiértékelést lehet végezni a referencia adatok ismeretében, így minősítve a mủanyag fedélben található rugó-csap megfelelőségét.

\section{Köszönetnyilvánítás}

A cikkben ismertetett kutató munka az EFOP-3.6.1-16-2016-00011 jelü „Fiatalodó és Megújuló Egyetem - Innovatív Tudásváros - a Miskolci Egyetem intelligens szakosodást szolgáló intézményi fejlesztése" projekt részeként - a Széchenyi 2020 keretében - az Európai Unió támogatásával, az Európai Szociális Alap társfinanszírozásával valósul meg.

\section{Irodalom}

[1] Hitomi, K.: Automation - its concept and a short history, Technovation 1994, 14(2):121-128. https://doi.org/10.1016/0166-4972(94)90101-5

[2] Ono, K., Hayashi, T., Fuji, M., Shibasaki, N., Sonehara, M.: Development for Industrial Robotics Applications, IHI Engineering Review 2009, 42(2):103-107.

[3] Bi, S., Liang, J.: Robotic drilling system for titanium structures, The International Journal of Advanced Manufacturing Technology 2001, 54:767-774. https://doi.org/10.1007/s00170-0102962-2

[4] Tsarouchi, P., Makris, S., Michalos, G., Stefos, M., Fourtakas, K., Kaltsoukalas, K., Kontrovrakis, D., Chryssolouris, G.: Robotized assembly process using Dual arm robot, Procedia CIRP 2014, 23:47-52. https://doi.org/10.1016/j.procir.2014.10.078

[5] Malamas, E.N., Petrakis, E.G.M., Zervakis, M., Petit, L., Legat, J.-D.: A survey on industrial vision systems, applications and tools, Image and Vision Computing 2003, 21(2):171-188. https://doi.org/10.1016/S0262-8856(02)00152-X

[6] Pfeiffer, F.: Assembly processes with robotic systems, Robotics and Autonomous Systems 1996, 19:151-166. https://doi.org/10.1016/S0921-8890(96)00043-7

[7] Rónai, L., Szabó, T.: Modeling and Robotic Handling of a Snap-Fitting Box Buckle, Pollack Periodica, Akadémiai kiadó, 2020, pp. 1-12. (cikk elfogadva, megjelenés alatt)

[8] Rónai, L., Szabó, T.: Intelligens robotmegfogó fejlesztése, Multidiszciplináris tudományok, Miskolci Egyetem, 2020, pp.1-6. (megjelenés alatt)

[9] Rónai, L., Szabó, T.: Snap-fit Assembly Process with Industrial Robot Including Force Feedback, Robotica, Cambridge University Press, 2020, pp. 317-336. https://doi.org/10.1017/S0263574719000614

[10] Rónai, L.: Design Aspects of a Robotic End-effector, Design of Machines and Structures 2019, 8(2):52-58., HU ISSN 2064-7522 